\title{
1. Disinterested Scholars or Interested Parties? The Public's Investment in Self-interested Universities
}

\author{
Hannah Forsyth
}

\section{Introduction}

The university's authority over knowledge is more tenuous than we think. The basis of university authority has been grounded, over the long history of higher education, in nothing more than ideas and values. Such ideas, however have taken institutions quite a long way. Other institutions - religious and political authorities, for example - have vied for a say over knowledge and yet the university has prevailed as the institution, arguably, that we trust the most. In the 20th century the university grew to enormous proportions and has gained significant influence. And yet it has arguably also faced more threats to both its standing and integrity than ever before.

Since the 1980s as universities became more overtly commercial, anxieties about the integrity of university knowledge have been raised. It is a worldwide concern. In 2011 the head of the London School of Economics resigned over a scandal that suggested funding from Libya's Gaddafi regime influenced that institution in academic ways. In Australia in 2013, Marcia Langton was criticised for her support of mining of Indigenous land in her 2012 Boyer lecture without disclosing the hundreds of thousands of dollars of research funding that her institute received from interested mining parties (Woolf 2011; Crook 2013). This chapter considers the growth of the entrepreneurial university in the context of academic freedom, for it is not only mining companies and political regimes that have an interest in knowledge. As universities became 
commercial entities themselves, they have developed a financial stake of their own in knowledge. What does this self-interest do to their credibility and their value to the public - and how does it relate to older ideas that universities ought to be 'disinterested' scholars, able to pursue knowledge objectively? It was a question that came to the fore in 2008 and 2009 when medical researcher Robert Gray made a claim for personal ownership of the wealth that resulted from the knowledge he produced, now reconceived by both Gray and his university as 'intellectual property' (UWA v Gray 2008).

Understanding university history is more difficult, in some respects, than other institutions, for longstanding traditions often infuse the way scholars speak about academic principles, as if scholarly values are universal and eternal. From the morally superior position such universal values provide, universities often seem connected to a theological-like theory of their place in society. Typically these values are attributed to Cardinal John Newman who, in the mid$19^{\text {th }}$ century, wrote a series of lectures whose title alone helps in this quest The Idea of the University - as if there was only ever one idea and it should stand for all time (Newman 1852. For critique, see Collini 2012, 39-60). Historicising the university more carefully allows us to consider instead what is at stake as university values have changed. This is particularly pertinent in the current political environment, where Coalition Education Minister Christopher Pyne seeks to deregulate university fees, propelling universities still further into the land of commercial values.

I will approach this particular history of universities from two perspectives, each derived from the issues central to what now seems to be at stake. The first is academic freedom, an ideal that has its own, and in fact quite troubled, history. The second perspective is the public interest. It is obvious to scholars that the public interest is compromised when academic freedom is undermined, but it is by a more thorough understanding of the history of universities that the importance of this link between academic freedom and the public interest can be more firmly established - refuting oft-voiced suspicions that academic freedom is merely an expression of self-interest by an already over-privileged scholarly élite.

Like academic freedom, the public interest is also a historically contingent concept. It is important that we understand it, however, for it is the reason our universities are maintained as they are. In the $20^{\text {th }}$ century, the public interest (and investment) in knowledge grew considerably. Knowledge defined and regulated labour supply and social capital; it underpinned economic growth with technological development and research; and it increasingly legitimised parliamentary decision-making. Indeed, by the end of the $20^{\text {th }}$ century, knowledge was a key element of national life, with universities its primary guardian. Universities were to educate the nation and make our labour market 
competitive; with new research, industries too would be able to compete internationally; they were guardians of ideas and values in art, music, history and philosophy, underpinning the disciplines that make us more than merely function; and they promoted and supported the health of the population, the security of food and the ethics and professionalism of Australian occupations. Since the mid-20 $0^{\text {th }}$ century, universities grew enormously, paralleling this growing public need.

Knowledge is so important that the public, its political representatives keep telling us, require universities to account to government bodies, reassuring them in constant, painstaking ways that universities working for the national interest. Why don't they trust us? We can gesture to a few things - rational choice theories that declare academics to be more likely to indulge in our hobbies than research, if we can get away with it; 'neoliberal' values that insist on a tangible return on public investment (see Redden 2008). But while such diagnoses are fair, such catch-all concepts deflect responsibility away from ourselves as scholars and, by pointing only to a past that we cannot recover, fail to show us a pathway by which we, within the scholarly community, might help to rebuild the public's trust.

\section{Academic freedom and the idea of the university}

Over the past two centuries, university academics have argued that certain scholarly freedoms are necessary to assure the integrity of knowledge. The grounds for their claims to intellectual and institutional autonomy have shifted, historically, as the idea of the university has adjusted to changing public need.

This long history of academic freedom is a bumpy one, continually negotiated under changing conditions (see Russell 1993). There was, of course, no original idea of the university. Medieval universities emerged in a messy, fragmented way, with no fundamental rules and principles. Universities across Europe were not separated from the church and the beliefs it espoused (Daly 1961). Medievalists tell us that university links to the church inhibited some scholarly freedoms, especially in philosophy and theology, but that the church also helped secure their autonomy. Ecclesiastical governance, characterised by autonomy from the state, gave universities a foundation on which to claim academic freedom in subsequent centuries (Haskins 1957, 50-7). German enlightenment values took the church's conventions of autonomy further, insisting on principles of academic freedom for their universities as a way of assuring the reliability of the research that was their hallmark (Fuller 2009). 
It was Wilhelm von Humboldt who formalised academic freedom in Germany in 1810, linking it not only to freedom from interference by other claimants to knowledge but also connecting it to what Newman would later describe as 'knowledge for its own sake', or curiosity-based inquiry, sometimes (but not always) historically associated with 'pure', rather than 'applied' research (McLelland 1980, 101-61).

As universities were established in the United States, they initially adopted this German, research-focused, model (Flexner 1930). With this model came ideas. Lehrfreiheit suggested that academics and their institutions needed a degree of autonomy to be able to do their job: Lernfreiheit was the freedom of students to choose their study and regulate the space in which they lived and worked (Macintyre 2010). But there was something different about American universities: they were not all conceived as state-run institutions. Because of this, there was a particular potentiality for being controlled by the private interests who funded them. By the late 19th century, progressivist educationalists like John Dewey argued that structural mechanisms must be put in place to protect knowledge from control by university trustees (Scott 2009). This was how, in American universities, academic tenure became so closely bound to the concept of scholarly freedom. The argument was that when private interests controlled the universities, only scholars secure in their employment could really pursue unbiased work. Because of the risk associated with private interests, American academic freedom was codified more extensively than in most other nations, by university professors themselves, not by the state or by institutional leaders.

American academic freedom had a dark side, however, argues Joan Wallach Scott (2009). She maintains that its proclamation in 1915 by the American Association of University Professors (AAUP) also functioned to enact the myth that knowledge (as truth) was separable from power. In so de-politicising scholarship, Scott suggests, the AAUP was complicit in the assertion of certain types of truths that themselves, as Michel Foucault famously argued, asserted a sometimes-insidious power (Foucault 1972).

In Britain, the interests at stake were quite different. As a result, there the key turning point in the development of academic freedom was when Cambridge and Oxford relinquished their religious test (requiring acceptance of the 39 Articles of the Church of England as a condition of enrolment) in 1871. This secularisation of universities freed scholars from some of the constraints experienced by thinkers of past generations. Nevertheless, such academic freedom did not assure a wholly independent scholarship since, throughout the 19th century, Oxford and Cambridge maintained strong links to British administrative and political power (Drever 1953, 17-24). 
Scholars seem to have felt, however, that far from being influenced by government they in fact did the influencing. It was not until government funding became central to the running of higher education in Britain early in the 20th century that university members became concerned. In the end, the autonomy of the universities was (at least theoretically) protected by the Universities Grants Committee, established in 1919 with the explicit aim of providing a 'buffer' between political interests and university spending - and thus scholarly priorities (Gallagher 1982; Shattock 1994).

Other systems intended to protect the integrity and quality of scholarship were also adapted from ecclesiastical conventions (Fuller 2009). Convocation, an assembly of members (usually alumni) who share responsibility for governance, evolved into the collegial systems of decision-making, legitimisation, course approval (or disapproval) and general academic authority that, prior to the 1970s, characterised our Australian universities and which were seen as key to academic freedom (Rowe 1960; Serle 1963). Such collegiality has not entirely disappeared: most public universities in Australia are still legally defined by their academic membership, even if this structure seems now to be rarely actualised. ${ }^{1}$ There is one recent exception. In 2014 an attempt was made to invoke an assembly of convocation at the University of Sydney to compel the vice-chancellor to represent staff views on fee deregulation in the public sphere. The University Senate quashed this attempt, in part arguing that convocation was unrepresentative of the relevant constituents and that, with hundreds of thousands of university graduates it is now too large to plausibly assemble (Gilmore 2014).

In the mid-20th century, academic freedom became central to debates about the university (especially research) worldwide. The asylum granted to German scientists and scholars fleeing Nazi Germany was perceived as much a mechanism to protect knowledge as it was to protect the scholars under attack (Ash and Sollner 1996). Let us not be too idealistic about this - it was a war of science and accumulating German scientists also deprived the Nazi regime of a key military tool. But it did prompt a new way of thinking about the political and economic value of knowledge that included philosophical reflections about the problem of allying ideas to political regimes. This marks a new phase in the history of academic freedom.

\footnotetext{
1 Of Australia's 39 universities, 36 are public institutions, 25 of which (or 67 per cent) are membershipbased. Membership-based institutions are organisations that are defined by their members, normally the academic staff, students and graduates. No university in Queensland is membership-based: seven of the nine public universities that are not membership-based are located in Queensland. The other two are the University of Canberra and the University of South Australia. (The various university Acts of Incorporation are found under the name of each university at Australasian Legal Information Institute: www.austlii.edu.au/.)
} 
German-Swiss author Herman Hesse captured the nuances of the 20th-century problem in his novel The Glass Bead Game, published in 1943. In this, he described Castalia, an idealised scholarly community (with its own flaws, not least a problem of legitimacy) that was created in contrast to an earlier era, which had 'insisted that Mind itself must serve politics or the military' (p. 338). Then, not only had scholarship been deployed for propagandistic purposes, it was also controlled so that 'not the faculty but His Excellency the General can properly determine the sum of two and two' (p. 334). It was a world of persecution or compliance for academics, where there was 'truly no pleasure and no honor in being a scholar or a writer' (p. 334).

There were, in fact, greater things at stake, Hesse's narrator shows, than the health and wellbeing of scholars. Compliant scholars did terrible damage:

The scholar who knowingly speaks, writes, or teaches falsehood, who knowingly supports lies and deceptions, not only violates organic principles. He also, no matter how things may seem at the given moment, does his people a grave disservice. He corrupts its air and soil, its food and drink; he poisons its thinking and its laws, and he gives aid and comfort to all the hostile, evil forces that threaten the nation with annihilation (Hesse 1970, 339).

It was this kind of public good that demanded academic freedom, protecting the nation from ideas (like fascism) that would undermine their civility. Public leaders such as Labor politician Kim Beazley (Senior) and CSIRO chair Ian Clunies Ross were concerned about the quality of research in postwar Australia because they believed the integrity of scholarly thinking was foundational to the integrity of the nation (e.g. CPD, 28 November 1958). Especially in postwar Australia, the public needed to be able to trust in the knowledge they needed and paid for. Hesse $(1970,338)$ put it this way:

We are specialists in examining, analysing and measuring. We are the guardians and constant verifiers of all alphabets, multiplication tables and methods. We are the bureaus of standards for cultural weights and measures. Granted, we are other things also. In some circumstances we can also be innovators, adventurers, conquerors and reintepreters. But our first and most important function, the reason the people need and keep us, is to preserve the purity of all sources of knowledge.

Joan Scott (or Michel Foucault for that matter) would undoubtedly not approve of the sense of universal knowledge or truth that this suggests, but it would have resonated at the time, not only with the international protection of German scholars but also with the lesson democratic governments believed they learned as a result of the Lysenko affair in Soviet Russia. 
In the 1930s, Soviet geneticist Trofim Lysenko proposed a theory of genetics that aligned to political sentiment, promoting collective farming. Agreement with Lysenko's theory was enforced and scientific genetics was inhibited - even prohibited-for decades. This not only repressed the development and application of genetics, however, it also had an immediate impact on an agricultural system already prone to failure and famine. Scientists knew that Lysenko's theory was never going to produce the agricultural yields needed to support the new industrial society, but they were not permitted to say so. Nor could they offer the solutions that would enable the regime to feed its population (Soyfer 1989). Western nations, thus alerted to the dangers of aligning scholarship to political goals, adopted the ideal that democratic states, by contrast to the Soviet and Nazi regimes, would protect academic freedom in their universities.

Nevertheless, despite inheriting centuries of tradition and new pressing reasons to protect academic freedom, in Australia in 1944, influential British scholar Eric Ashby observed that universities here were under more threat from political and sectarian influence than in other Commonwealth countries (Ashby 1946). Due to regular external pressures on the nation's universities, Australian vicechancellors were notoriously wary of government interference. Indeed, this was a key frustration for CSIRO chair Ian Clunies Ross, who expended considerable energy in the late 1940s and early 1950s encouraging vice-chancellors to petition the Commonwealth government for ongoing financial support of the State-funded universities, finding that (despite working in quite impoverished conditions) vice-chancellors feared the government influence associated with funding (1955).

Eventually Clunies Ross was successful in persuading both the universities and the Prime Minister, Robert Menzies, to conduct a review. In 1957, the Murray Review of Australian Universities established a national framework for funding and conceptualising the university for the national good. It recommended that the Commonwealth invest considerable sums in higher education and that a buffer body like the British Universities Grants Committee be established to administer this funding (Murray et al. 1957).

From within the universities, the government was being watched closely. In this period, scholars were particularly anxious about their freedoms. News of ASIO surveillance in the universities and of reports of the loss of academic freedom in the United States under Senator Joseph McCarthy's anti-communist policies, led academics to scrutinise the Murray report meticulously (Buckley and Wheelwright 1958). All seemed to be well, at least as far as the Murray report was concerned. Even though there was plenty of evidence of ASIO surveillance in universities, Menzies was generally accepted as a 'university man' 
(Forsyth 2014). For the most part, historians have since acclaimed his habit of protecting university autonomy from interference by other, less sympathetic, politicians (Martin and Hardy 1999; Bessant 1977).

Confidential cabinet documents held in the Australian National Archives, however, tell a different story. Much as Menzies was sympathetic to the universities, he was also compelled to ensure that federal funding resulted in national benefits. While scholars considered the Australian Universities Commission to be a buffer body like its UK counterpart, Menzies instead saw it as the vehicle for assuring fulfilment of government goals. To Cabinet, he argued that 'Money is the weapon by which oversight of universities will be secured' (Menzies 1959). He went on to describe the kind of details that he hoped government would be able to influence, a hope also reflected in his assessment of the Mills report, which he submitted to parliament some years earlier (Forsyth 2012). While the kinds of things Menzies sought to control were fairly modest - buildings, equipment and so on - it did open the universities to more government control than they were led to believe. Historians Peter Tannock (1975) and AP Gallagher (1982) both showed the ways that Menzies' legislation gave latent potential; for government control. Moreover, there is plenty of evidence that this worked, though slowly: the Australian Universities Commission mediated gradual but steady increases in government involvement in university business (Gallagher 1982).

When Gallagher published his book, the most significant threat to university autonomy was still five years away. The 1987 Dawkins reforms not only removed the buffer between government and higher education, government also clawed back recurrent university funding and redistributed it competitively, with the Commonwealth's economic goals a priority criterion for funding allocations (Aitkin 2000). Closer government involvement in the minutiae of university affairs was led by, among other things, a belief among Australian politicians that, left to their own devices, universities were unlikely to work towards the public benefit (Redden 2008).

This is a well-known story. Labor Minister John Dawkins retains a kind of 'bogeyman' status in the narrative of Australian universities. It is time, I argue, for us to complicate this narrative - for if we fail to do so, we may well never get past our tendency to recall a mythical pre-Dawkins 'golden age', allowing nostalgia, or a desire to return to a past irrevocably lost, to hold us back from solving the problems higher education now faces. A key reason that history is important is that it shows how things have changed - this can help us to do more than understand what went wrong in the past. By identifying changes in context and need, it can help us know what to do now. 


\section{The public interest and the idea of the university}

Accountability by universities for the public interest was always in tension with university autonomy. This is in fact a structural tension, inherent to publicly funded universities, and must be continually negotiated (Russell 1993). In 1944, for example, University of Sydney Vice-Chancellor Sir Robert Wallace argues that the Chair of the Universities Commission, Richard Charles Mills, had the 'wrong attitude' when he wanted the university to run building plans past the government that funded them (Universities Commission 1946).

Perhaps it says something of the place of universities in society that Sir Robert was confident enough to be so blunt - though of course he also knew Mills well; they had been colleagues at Sydney University for years. Nevertheless, it was, in fact, a wholly different scholarly world, which we would now struggle to recognise - or indeed condone. Before the Second World War there were only six universities, educating less than 0.2 per cent of the population, a vast majority of those the children of the top 10 per cent of the nation's earners. They were public universities but served very narrow public functions.

Not all of the founders of these six public universities intended for higher education to manufacture and sustain social and financial privilege. Indeed, as Julia Horne and Geoffrey Sherington argue, merit was a key colonial value that infused the establishment of the University of Sydney in particular, with the result that a wider demographic than is often imagined attended university from early days (Horne and Sherington 2012, 48-51). Despite this, when it came to universities the public interest was imagined rather narrowly (and so, in fact, was merit). Universities should educate the best, believed William Charles Wentworth (1853), in order to establish an Antipodean aristocracy, forging society's leaders.

Academics, too, were not what they are now. Professors were figures of public importance whose arrival, normally from Great Britain, was announced in the newspapers, as was their attendance at official functions, where their wives' outfits were documented as items of public interest (SMH, 2 August 1938). The public's interest, it seems, was also quite narrowly conceived.

This world of privilege was not wholly self-serving. Their high social standing enabled academic staff to promote the university and their disciplines in the public sphere and many did so to great effect, including in offering public lectures. Within their institutions, scholars protected and imparted knowledge by reading, teaching and setting examinations (including matriculation examinations at the end of secondary school) that would test and assure the 
accuracy of their students' learning. This was indeed a public service, though their conceptions of merit were also aligned to class-based attributes, so that they tended to benefit the children of Australia's elite (Forsyth 2014).

What pre-war academics rarely did was research. There was some research, especially in medicine and agriculture, but the research culture that we now consider to be core to the idea of the university did not emerge in Australia until the postwar period, when research and innovation became key to Australian defence strategy and economic growth as well as to our standing as a democratic and civilised nation on the international stage. The Humboldtian tradition that infused the German research universities had little impact on the British tradition - and thus limited influence in Australia - until the experience of war demonstrated to government and the public that investment in research carried with it a significant and sustained public good (Flexner 1930, 56-61).

The change was rapid, but not universal. An American Carnegie Foundation visitor in the 1940s found that most professors considered their central role to be the protection of 'standards' in the universities, not research or innovation (Conant 1951). The PhD had no real place in Australian universities until the 1940s. Even in the 1950s, many remained against it, arguing that scholarship the kind of 'mastery' of a discipline that defined the British MA tradition - was the longer, harder and more important route to expertise than the 'horribly American' PhD, which privileged mere discovery of something new (Connell 1995, 204-8).

But the postwar era required research and lots of it. This emerged from wartime and quite a lot of the research conducted both within the universities and the CSIRO had military application. More importantly, the 'mobilising' mentality of war, which had contributed to everything from optical munitions to malaria treatments, from psychological testing of combatants to social scientific studies of morale, extended into the peace. The awareness of the value of research that came from the war effort slipped into an ongoing necessity of research for the national good (Hobbins and Forsyth 2013).

The new era of nation-focused research was launched, though not without some effort from government researchers, especially Ian Clunies Ross, and university researchers, such as Marcus Oliphant. Atomic energy, diplomacy in Asia and the Pacific, technological innovation to support agricultural and manufacturing industries and engineering advances to facilitate mining and energy production were all key priorities. Medical research and population health management were also emphasised. This was not just a scientific revolution. Research supporting wartime 'morale' developed into a robust system of social scientific inquiry (Pomeroy 1995; Macintyre 2010). The research culture that often dominates contemporary expressions of the 'idea of the university' emerged 
not from 'pure' inquiry by groups of cloistered academics, but from a sustained and (often) Commonwealth-funded period of conscious nation building, with research that aligned to government strategy.

This link to government did not go unnoticed. When they were not gossiping over the salacious Orr case involving a seduced student at the University of Tasmania, the debate in university corridors in the 1950s was whether universities should be 'ivory towers' or 'service stations' to government and the public interest. By the mid-1960s, most scholars conceded that the service station side had won out. Political philosopher Perce Partridge (1965) argued: 'It is no longer a wry jest: universities are now, in considerable part, public utilities or instrumentalities. They are being increasingly supported by governments from public funds because they carry out public functions, as hospitals and public transport systems do.'

The key cause of this shift was the significant injection of funding to the universities by the federal government after the 1957 Murray Review. Just as educators in America noticed the connection between money and ideas as their trustees asserted their influence, so also Menzies' monetary 'weapon' had a significant effect on the universities. From one perspective, it gave the government the tool with which they could control universities in the public interest.

The public's interests and the government's, however, were not necessarily the same thing. This is the other story that could be told - and which was told by the student radicals who occupied university campuses from the late 1960s to the mid-1970s. Democracy and the public good might also be served by dissent, by offering divergent ideas to the public sphere. The 'truths' that governmentsanctioned research inculcated also oppressed, failing in particular the more vulnerable of society by perpetuating ideas about economics, race, gender and sexuality as 'truths' that in fact benefited the already-powerful (Giroux and McLaren 1989). They argued that although government had an important role in funding knowledge for the public good, universities must also remain independent from government, enabling a questioning and expansion of the idea of the public good itself.

Despite these critiques, however, the government's postwar investment in research was indisputably beneficial to the public. As a result of that investment, we inherit, in universities, a spectacular record of research. Despite the large literature on the decline and fall of the university, in Australia and internationally, everything from snake anti-venom, public health, food safety, addressing climate change, safer mining, revival of Indigenous languages, better power sources and more productive international relations have emerged (and continue to emerge) from university research culture. 


\section{The evolution of self-interested universities}

And yet, on the other hand, everywhere we look we see symptoms of a sickness so ingrained it is tempting to despair. Universities have become focused on their own commercial self-interest, the symptoms of which are in the growing managerialism, neoliberalism, audit-culture, casualisation and student consumerism (see Shore and Wright 2008, 57-89; Hil 2012). These broad concepts, however, do not give us the specific causal history that properly explains the contemporary university - and without understanding these causalities, our responses to the problems we face are limited.

While the 1987 Dawkins reforms were revolutionary, there is plenty of evidence to suggest that many of the issues were already emerging in the universities without much help from government at all. For an explanation, we need to look back to the 1970s where, even though going to university was finally free of tuition fees, students were not enrolling at the rates universities had come to expect. There were, it seems, several reasons for the decline in growth. One was that the growth experienced before this was propped up by the baby boom - by the mid to late 1970s that population bubble was almost all through university.

The completion of tertiary education for the baby boomers did not fully explain the shift in the pattern of student demand, for there was also a significant shift in the percentage of young people choosing university. This was due, from all contemporary analyses, to a perception that a university education no longer assured a 'university type' job on completion, a result of a shifting economy that had not quite shifted yet to accommodate recent graduates and a government policy framework that could no longer support full employment (Gross and Western 1981). Widespread inclusion of university graduates in a changing labour market was impeded by the effect of the oil shocks, which contributed to rising unemployment. This interrupted development of the 'knowledge economy', sought by the likes of prominent American educational leader Clark Kerr. This relocation of competitive advantage to creative, flexible and innovative ideas (rather than the efficiency of production) was in part a symptom of an economy that had been shifting for some decades away from a predominance of unskilled or semi-skilled labour towards white-collar professions, including the growth of a managerial class, service professions and the finance sector. Some of this shift was to be fuelled, according to Kerr, by the larger number of university-educated youth graduating in the 1960s and 1970s (Kerr 1972).

The sudden shortage of public money in the second half of the 1970s under the conditions of 'stagflation' had a more immediate and pressing effect as the Fraser government began to seek cost savings from a university sector that had become accustomed to more substantial growth. Experts in higher education called it 
the 'end of the golden age' and indeed they were right (Gross and Western 1981). At the OECD in 1980, higher education leaders collectively declared an international crisis in the perceived value of higher education. There was a 'real danger', they agreed (OECD 1983, 8), that if the current crisis in public confidence in higher education continued, the university 'could be seriously and perhaps irretrievably compromised'.

It was also in 1980 that Rupert Murdoch's The Australian newspaper launched its 'Higher Education Supplement'. Between coverage of the successful opposition by staff and student unions to Malcolm Fraser's 'razor gang' cuts to higher education, the Supplement began to profile a new type of academic ideal. A modern, American-style entrepreneurial academic who did not whinge about declining sources of income, who sought his own industry-based research funding, taking a commercial stance to his work, began to be held up, in the Supplement, as the academic who would meet the challenges of the 1980s. He (sadly, still mostly males were represented, even though feminism was now important in the universities) was contrasted to the bumbling ineptitude of the grotesquely caricatured British 'layabout don' (e.g. Bremer 1982; Hamilton 1980; Johnson 1982; Anon 1980a, 1980b, 1983; Ford 1983, 1984; Howard 1983; Trinca 1984).

With a shortage of students to keep government income flowing, by around 1980, Sydney University began to advertise. Initially shocked and betrayed, accusing Sydney of 'selling themselves like soap powder', by 1982, the other universities joined in. ${ }^{2}$ Nevertheless, growth slowed to its lowest point since the withdrawal of the Commonwealth Reconstruction Training Scheme in the 1950s (DETYA 2000). Salary and other costs, of course, were not slowing in the same way, causing problems (Macintyre 2013).

Vice-chancellors and others deployed the 1980s catch-phrase 'more scholar for the dollar', as they sought cost savings (Ferguson 1981). The division between the vice-chancellors and their staff, growing since the 1950s, widened still further, threatening the collegial culture of university governance (Ferguson 1981). Shortly after the Hawke Labor government was elected, universities were establishing research commercialisation offices to seek additional sources of income (Dawson 1984; Morris 1984; Anon 1984, 1985; Stanton 1984; Simmonds 1985).

Many vocal scholars within the university were in favour of complete deregulation. Students did not value higher education, argued the most vocal of these neoliberal voices, Don Watts from Western Australia Institute of

2 'Problems of Campus Promotion', HES, 16 April 1980; 'Competing for Student Advantage', HES, 27 January 1982. 
Technology, because it did not cost anything (Watts 1987, 35). The relationship between price and value, which sat lightly on course fees from the beginning, ${ }^{3}$ now began to infuse the debate about the real value of free education, which remained, for the time being, policy for both Labor and the staff and student unions (Marginson 1993, 180-2).

By the mid-1980s, a compromise proposal was taken seriously. Higher education, ANU economist Helen Hughes (among others) argued, could be turned from a liability into an asset by charging fees to international students, establishing an educational 'export market'. With the low price of Australia's key commodities causing significant problems for the balance of trade, a new export market was an attractive proposition. For universities, the opportunity to charge international student fees was a lifeline many felt they could not ignore (Hughes 1988, 217-46).

Within a year of that initial reform, the Dawkins green paper was released (Dawkins 1987a). The key reforms intended to facilitate a shift in Australia's economic foundations towards 'human resources and labour force skills' and to make universities and workplaces more responsive to shifts in the global market (Dawkins 1987b). Reforms led to the inclusion of many more students from wider social backgrounds in a mass system, which also extended the benefits of higher education to more members of the community (Robinson and Rodan 1990, 22; James et al. 2013, 126-45). The result, Labor hoped, would be a 'clever country', an aspiration that Dawkins claimed he fed to Prime Minister Bob Hawke (Cain and Hewitt 2004, 41).

The stain of 'layabout dons' still did not go away. The Liberal 'waste-watch' committee began to ridicule the titles of publicly-funded research projects and government began to crack down on 'hobby' research - one element of the reasoning behind a claw-back of recurrent university funds, re-allocated competitively through the Australian Research Council (Baume 1987).

For similar reasons, vice-chancellors were under increasing pressure to manage the performance of their scholars. 'Managerial' changes were implemented, sometimes with government backing, sometimes on university leaders' own initiative. Not all of the criticisms of academic performance were unearned. Since I began researching the history of Australian universities in 2008, many scholars have shared stories from the 1970s and 1980s, telling of long scholarly morning teas, which indeed sometimes (though not often enough to justify them)

3 When the NSW University of Technology (later renamed University of NSW) was setting its first course fees, they wished to be more accessible to working-class students but nevertheless did not pitch course fees much lower than Sydney University so as not to 'devalue' the degree. This is quite different from the market signals associated with higher fees: whereas the latter are concerned with attracting students in a market, the former was about the value of the UNSW credential for graduates in the labour market (NSW University of Technology, 1947). 
resulted in some interesting research collaborations and collegial discoveries. The expectation to publish and to do so extensively was not yet widespread so failure to do so cannot be measured in the same terms that might be applied today. But then, as now, while we wish all scholars behaved with integrity, some did not. The downside to collegiality, as Herman Hesse's novel pointed out, was a self-serving legitimacy (Hesse 1970, 324-43). It offered governance structures that could and often did function as an exclusive 'boys' club', as many women academics will testify and also fostered some lax work patterns (Marginson and Considine 2000,116). In some ways, in audit culture, academics got the external scrutiny they deserved. ${ }^{4}$

But in unravelling collegial structures and (in attempting to keep them more honest) re-focusing the universities and their scholars to monetary gain, there were unintended effects. The shift in emphasis to commercial entrepreneurialism had an ontological impact. The economists now dominating Canberra's corridors preferred the phrase 'positive externalities' to what Ian Clunies Ross and others would once have called 'civilisation' (Stanford 1986). The 'real' value of knowledge was in its exchange, defined by the money commodity, not by any contribution to civilisation, which itself seemed an outdated concept. As a result, in widespread public discussions about academic freedom, many expressed bewilderment over what academic freedom was for. When knowledge had mere monetary value, academic freedom became a 'tradition', as antiquated as 'civilisation' but more damaging: offering unearned license to the intellectual elite (Biggins 1984, 6-9).

As these discussions grew louder and universities shifted towards a more entrepreneurial stance, the language used to describe knowledge changed. A key term, which helps to identify the change, was 'intellectual property'. Intellectual property became important partly because, as research commercialisation increased, legal protection of inventions became a significant legal concern. The language of property, however, spread far further than its legal necessity (Monotti and Ricketson 2003; McKeough and Stewart 2004, 19). While knowledge is not in fact the same as intellectual property, the application of the concept of property to knowledge resonated with the cultural and structural changes the universities were experiencing. Afterwards it became possible to say this (ANU Research Office 2013): 'Intellectual property lies at the heart of all basic, strategic and applied research conducted across all Colleges and disciplines at the ANU. Put simply, IP is the ANU's core business: it's what we produce.'

4 While scrutiny seems to have led to increased productivity, it has not done much for scholarly integrity. Indeed, if the gossip among research assistants is anything to go by, it seems likely that the decline of collegial scrutiny, replaced by more bureaucratic structures, has led to a sense of entitlement, perhaps in fact caused by audit culture. This has prompted the use of ARC and other university funds in ways that more closely resemble the travel habits of Chrysler CEOs than publicly funded scholars seeking knowledge for the public good. 
Knowledge was no longer something the universities protected (or guarded or imparted) as an intrinsically valuable substance. It became the commodity commercial universities produced and traded for money.

In the 2008-09 case of UWA $v$ Gray, it became evident, at least to the presiding judge, French J., that this restructure of university motives refocused them away from the public interest and towards their own. In fact, everyone's selfinterest was at play in this case, as medical researcher Robert Gray sought the approximately $\$ 75$ million value on his research as his own, while the university wanted it for the institution. In this case, however, UWA argued that as a trading corporation, its academic staff had a responsibility to protect its financial interests. The Federal Court disagreed. Examining the UWA Act, the Court maintained that an academic was responsible for producing and protecting knowledge for the public interest. Moreover, it was impossible for academics to do so if they must prioritise the university's commercial interests, even though no one wished for Gray to profit as he did. Unless the university was structured in a way that provided the academic freedom that enabled academic staff to put knowledge before profit, the university was unable to perform its task or fulfil its public responsibility in accordance with its Act.

Australia's higher education sector was shocked when the court found against UWA. In particular, the sector's intellectual property lawyers (who had the most to lose from the decision) were profoundly concerned (Lane 2010). Outraged, members of the legal profession argued that the finding reflected an outdated conception of the university. Justice French, they claimed, failed to notice that in recent years the modern university has a commercial purpose (Lawyers Weekly, 9 July 2009; Bushby 2009).

This was why patent lawyers, like all of us in the universities, need history. Without understanding why the Court (which had a better grounding in history than UWA's lawyers) considered it to be important that the university protect knowledge first, patent lawyers across Australia were unable to see that there was more than money at stake. This made them blind to the real issues, leading the sector to encourage UWA to appeal. The Court's mistake seemed so obvious, they were sure that they would succeed before the Full Bench of the Federal Court. In 2009, UWA appealed and failed. UWA only strengthened its argument that the responsibilities of university staff should be the same as any other employee of a profit-making organisation. In response, the Court only strengthened its position that if academics were subject to the commercial interests of their employer that would give the universities the right to suppress research evidence, edit research findings or limit the release of research to the public if that would benefit the university from a financial perspective. The Court could see that structuring academic priorities to the university's self- 
interest was not in the public interest. It was academic freedom, structured into institutions, that helped ensure the public could access and trust university knowledge.

Financial interests, however, were not necessarily the primary motivation for university leaders throughout the many changes that built entrepreneurship into higher education. The shift in language and priorities as value began to be measured in dollars did not wholly shift university attention to money for its own sake. Rather, universities sought money as an indicator of esteem. Esteem sat close to longstanding university traditions, for it measured the relative value of what academics did. The extent to which a scholar's work - their teaching, research, scholarship and scholarly character - was valued by other academics contributed to their authority and voice in the public sphere. When esteem was increasingly attached to income, universities sought it vociferously. You can see it on a smaller scale when humanities scholars mention they need a grant - but that they need it to meet esteem measures, not because they need the money to actually perform the research tasks (Forsyth 2014; see also Brennan and Petit 2004).

\section{Conclusions}

University claims to a right to academic freedom are based on the need for institutions to protect the integrity of research and scholarship if they are to be of much value. The belief that such things can be protected through academic freedom rests on an assumption that separating scholarly inquiry from political, sectarian and financial interests will assure quality work. It is not really a very complex idea, akin to the need, common in several spheres, to avoid conflicts of interest. Historically, universities had this structured into their institutional frameworks in order to assure that their priorities were focused to the public interest, rather than their own.

This is not to suggest that their own interests were ever absent: I am not making the case that academics were once objective and now are not. In the 1980s and 1990s - in fact even into the 2000s - postmodern sensibilities rightly required us to acknowledge that the university and its scholars were never in fact as 'disinterested' as they claimed. They were not only aligned to sets of knowledges and values that regulated social interaction, as Foucault demonstrated, they were also often directly aligned with the interests of the state (Foucault 1972). Sins of omission can be included in this, since, as Raewyn Connell has demonstrated, the exclusion of certain sources of knowledge in the university means the institution has gone beyond legitimising nations to also prop up Western global dominance (Connell 2007). For Indigenous knowledge in 
Australia, the consequences have been lasting and tragic, but will hopefully not remain so forever. But while we must have this discussion, the suggestion that universities should be structured to protect knowledge from their own financial self-interest does imply that I also argue for an 'objective' scholarship. There has always been an element of self-interest in academic work, but this does not excuse structuring financial self-interest into the pursuit of knowledge. Placing academics in a system of obligation so that the knowledge they produce and protect is measured against more than whether it earns money is what makes the university different from commercial research and development, applied government science and private schools of tuition.

Several realities intersect at this point. Do university leaders really care about money - or is that money just a signifier while institutional structures compel motives that are really about esteem, which forms the basis of much scholarly authority? From the perspective of the integrity of knowledge it does not matter a lot, for both have clearly required institutions to sacrifice their dedication to autonomy and academic freedom on the altar of commercialisation, even if the money has primarily symbolic power.

Certainly by the 1990s universities were reconceptualised as an industry, shaped by their competition with one another for government support, student fee income and industry backing. No longer really the public institutions they had been formed to be, the institutions themselves sit at odds with the academics they house. Compelled from one historical angle to put knowledge first, institutional leaders re-imagined their fiduciary obligation to the institution in ways that sometimes contradicted its older mission to protect knowledge, as the case of $U W A v$ Gray demonstrated, transferring their allegiance instead to their (also very real) responsibility for institutions' financial sustainability.

This seems, when we consider the long history of universities, short sighted and irresponsible. The university is a historical phenomenon, albeit a remarkably resilient one, but there is no reason it should last forever. Its ongoing existence is dependent on the maintenance of that which gives the university its special authority and indeed its reason for being - an authority over knowledge derived from public trust in its special, independent integrity. 
This text is taken from Through a Glass Darkly: The Social Sciences Look at the Neoliberal University, edited by Margaret Thornton, first published 2014, this version 2015 by ANU Press, The Australian National University, Canberra, Australia. 